\title{
中世古典文学におけるテキストマイニングの試み
}

\section{Attempt of text mining for the medieval literature of Japan 深澤克朗"*, 沢登千恵子 ${ }^{2}$ \\ Katsuroh FUKASAWA ${ }^{1 *}$, Chieko SAWANOBORI ${ }^{2}$}

1 専門学校サンテクノカレッジ

Suntechno College

厂400-0111 山梨県甲斐市竜王新町1999-5

E-mail: fuka@suntech.ac.jp

2 専門学校サンテクノカレッジ

Suntechno College

厂400-0111 山梨県甲斐市竜王新町1999-5

E-mail:chieko@suntech.ac.jp

*連絡先著者 Corresponding Author

本稿では、中世古典文学の数作品について「係り結び」を構成する係助詞の頻度を計測し、それ をベースにテキストマイニングを試みた。統計的手法としては、比率の検定、主成分分析、クラスター 分析、判別分析を行った。「係り結び」は鎌倉・室町時代あたりから衰退が起こってきているといらこと が定説であり、本稿の作品群においても、時代を追ってその傾向が見られる[1][2]。さらに、その作品 間での差を段単位での係助詞の頻度により調査した。その結果、「宇治拾遺物語」は他の作品とは 差があるといら傾向が見受けられた。

In this paper, we measured the frequency of the binding particle which constitutes a "Kakarimusubi" in the several medieval literature and we tried text mining with it. The statistical method, test of proportion, principal component analysis, cluster analysis, discriminant analysis were carried out. In the established theory, "Kakarimusubi" is declined over "Muromachi" era from "Kamakura" period. Because "Bushi" became to have a great power, and didn't use "Kakarimusubi" which was the word of aristocrat. In this paper, the trend can be seen chasing the era. Further, we investigate the difference between the work by each chapter's frequency of the binding particle. As a result, a different tendency is seen between "Uji Shūi Monogatari" and the other literatures.

キーワード: 係助詞, 係り結び, テキストマイニング, 主成分分析, クラスター分析, 判別分析、宇治拾遺物語 Keyword: Binding particle, "Kakarimusubi", Text mining, PCA(Principal Component Analysis), Cluster analysis, Linear discriminant analysis, "Uji Shūi Monogatari" 


\section{1 はじめに}

近年、コンピュータ能力の飛躍的な増大と データ解析技術の普及に伴い、テキストマイ ニングという分野が開拓されてきている。テ キストマイニングとは、データの計量的解析 を様々な角度から行い、何らかの特徴の抽出 を目的とするものである。本稿では、平安・ 鎌倉時代の有名な6作品を対象にした計量分 析を行った結果について報告を行う。古典文 学を対象にした計量研究としては、安本美典 による「源氏物語」における『宇治十帖』の 別作者説、村上征勝らによる「源氏物語」の
助動詞の計量分析、前田亮らによる古典史料 のテキストマイニングなどの研究などがあ り、近年様々な分析・研究がなされてきてい るが、テキストマイニングの対象としての古 典は、さほど行われてきているわけではない [3] [4] [5]。これは、古典が現代語と異なり、 文の長さをとってみても、その定義は様々で あり、古代・中世・現代では文語・口語とも 相当な違いがあり、さらに、古語への専門知 識が必要であることもその一因と思われる $[6]$ 。

表1 作品中に使用された係助詞

\begin{tabular}{|c|c|c|c|c|c|c|c|c|c|c|c|c|c|c|}
\hline & \multicolumn{2}{|c|}{ 伊慜物語 } & \multicolumn{2}{|c|}{ 土佐日記 } & \multicolumn{2}{|c|}{ 枕草子 } & \multicolumn{2}{|c|}{ 更級日記 } & \multicolumn{2}{|c|}{ 宇治拾遺物語 } & \multicolumn{2}{|c|}{ 徒然草 } & \multicolumn{2}{|c|}{ おくの細道 } \\
\hline 刊行年 & 92 & & & 34 & 10 & & 10 & & $\begin{array}{l}\text { 12世紀 } \\
\text { 13世紀 }\end{array}$ & $\begin{array}{l}\text { 己末 } \\
\text { 己前半 }\end{array}$ & 133 & $0 \sim$ & 170 & \\
\hline 単語数 & 14,879 & 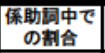 & 7,122 & $\begin{array}{c}\text { 倸助詞中で } \\
\text { の聙合 } \\
\end{array}$ & 68,345 & $\begin{array}{c}\text { 保助调中で } \\
\text { の幰合 } \\
\end{array}$ & 15,369 & $\begin{array}{c}\text { 倸助调中で } \\
\text { の幰合 } \\
\end{array}$ & 110,164 & \begin{tabular}{|c|} 
係助调中で \\
の劃合 \\
\end{tabular} & 41,671 & 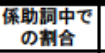 & 11,165 & $\begin{array}{l}\text { 係助司中 } \\
\text { での㛃合 }\end{array}$ \\
\hline ぞ & 59 & 0.198 & 76 & 0.475 & 362 & \begin{tabular}{|l|}
0.238 \\
\end{tabular} & 63 & \begin{tabular}{|l|}
0.250 \\
\end{tabular} & 577 & 0.374 & 170 & 0.253 & 19 & 0.13 \\
\hline なむ & 73 & 0.245 & 18 & 0.113 & 111 & 0.073 & 26 & 0.103 & 124 & 0.080 & 12 & 0.018 & 3 & 0.02 \\
\hline や & 87 & 0.292 & 38 & 0.238 & 306 & 0.201 & 77 & 0.306 & 272 & 0.177 & 147 & 0.218 & 73 & 0.49 \\
\hline か & 49 & 0.164 & 19 & 0.119 & 263 & 0.173 & 50 & 0.198 & 283 & 0.184 & 150 & 0.223 & 45 & 0.30 \\
\hline こそ & 30 & 0.101 & 9 & 0.056 & 481 & 0.316 & 36 & 0.143 & 285 & 0.185 & 194 & 0.288 & 10 & 0.07 \\
\hline 係助詞 (合計) & 298 & 0.020 & 160 & 0.022 & 1,523 & 0.022 & 252 & 0.016 & 1,541 & 0.014 & 673 & 0.016 & 150 & 0.01 \\
\hline
\end{tabular}

$\mathrm{A}$ 単語数からみた係助詞の割合

\section{2 分析}

\section{1 対象作品と分析環境}

本稿においては表 1 にある 7 作品につい て分析を行った。「おくの細道」は江戸初 期の作品であるが、比較のために掲載した。 表 1 より、係助詞は時代が進むにしたがい、 徐々に使われなくなってきている感がある。 対象作品のデータは、後述した参考文献に URL を記載した [7]〜 [13]。形態素への分解 は国立国語研究所で開発された中古和文 UniDic と『茶まめ』を用いて行い、係助詞 の頻度 (係助詞数/総単語数) を計測した。 なお本稿では係助詞は「ぞ」「なむ」「や」 「か」「こそ」の 5 種に限定した。係助詞に は「は」「も」もあるが、これらは文末を終
止形に拘束しているということではあるが、 半藤英明の理論より係助詞とみなさない立 場で、除外して計測を行った [14]。また、 作品の各段 (章) 単位での分析は「伊勢物 語」「枕草子」「宇治拾遺物語」「徒然草」に ついてのみ行った。統計分析環境は、 $\mathrm{R}$ を 用いて行い、判別分析については、福井正 康氏（福山平成大学）の開発されたソフト ウェア「College Analysis」を使用させてい ただいた $[15][16]$ 。

\section{2 係助詞の比率の検定}

前述した 7 作品から 2 つ選択して、その 作品間での係助詞全体の頻度において有意 な差があるか否かを検定した。 
表2 集団比率の検定

\begin{tabular}{|l|r|r|r|r|r|r|r|}
\hline & 伊勢物語 & 土佐日記 & 枕草子 & 更級日記 & 宇治拾遺物語 & 徒然草 & おくの細道 \\
\hline 伊勢物語 & & $1 . \mathrm{E}+00$ & 0.9723 & $3 . \mathrm{E}-04$ & $5.85 \mathrm{E}-14$ & $2.45 \mathrm{E}-06$ & $2.6 \mathrm{E}-07$ \\
\hline 土佐日記 & & & $9.5 \mathrm{E}-01$ & $1.9 \mathrm{E}-03$ & $9.0 \mathrm{E}-09$ & $1.8 \mathrm{E}-04$ & $5.3 \mathrm{E}-06$ \\
\hline 枕草子 & & & & $5.4 \mathrm{E}-06$ & $2.2 \mathrm{E}-16$ & $2.0 \mathrm{E}-12$ & $1.9 \mathrm{E}-09$ \\
\hline 更級日記 & & & & & $2.0 \mathrm{E}-02$ & $8.7 \mathrm{E}-01$ & $5.8 \mathrm{E}-02$ \\
\hline 宇治拾遺物語 & & & & & & $1.9 \mathrm{E}-03$ & $6.7 \mathrm{E}-01$ \\
\hline 徒然草 & & & & & & & $4.4 \mathrm{E}-02$ \\
\hline おくの細道 & & & & & & & \\
\hline
\end{tabular}

表 2 より、太字の部分が有意水準 $5 \%$ ない 1\%で有意差がみられたものである。しかし、 平安時代初期の「伊勢物語」「土佐日記」

「枕草子」においては、有意差が見られな かった。他においては、大半は有意差があ り作品間での違いがみられる。

\section{3 作品全体での分析}

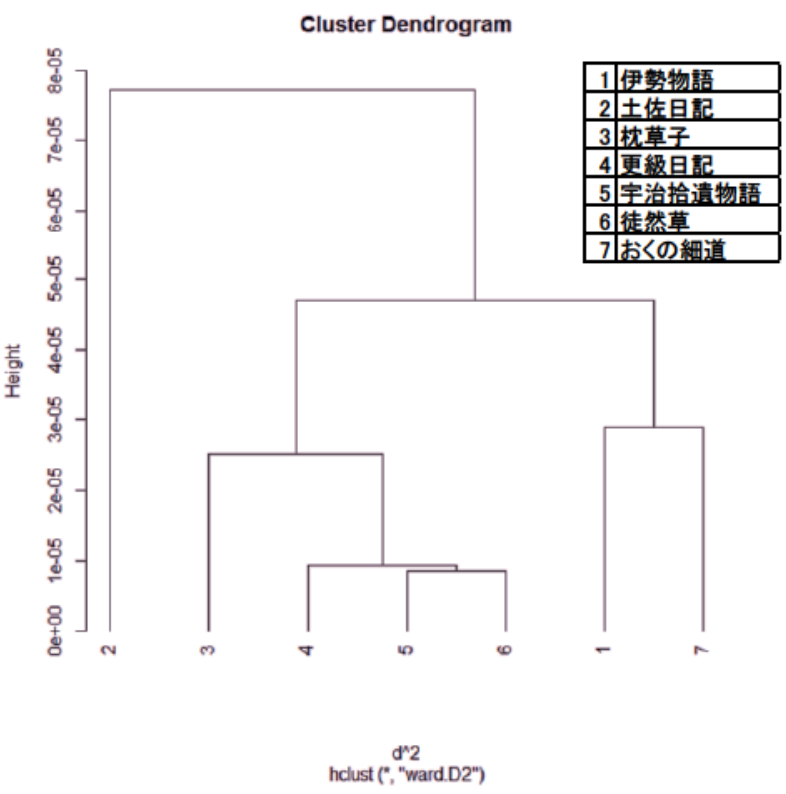

図1 作品全体のクラスター分析

図 1 に全作品のクラスター分析（階層的 分析）による樹形図を記す。図より「土佐 日記」が最も類似度がなく、「伊勢物語」 と「奥の細道」が近いように見受けられる が、3〜6の「枕草子」「更科日記」「宇治 拾遺物語」「徒然草」において類似度が高
いことの方が強く判断できる。これは、ク ラスター数を指定した非階層的分析で明ら かになった。

さらに非階層分析でのクラスター数は、 どのくらいが適切であろうかという問題が ある。通常は因子分析を使う場合が多いが、 ここでは係助詞の組み合わせによる傾向を みる意味で主成分分析を使用した。

表3 主成分の固有値と寄与率

\begin{tabular}{|c|c|c|c|c|c|}
\hline 主成分 & PC1 & PC2 & PC3 & PC4 & PC5 \\
\hline 固有值 & 2.00 & 1.65 & 0.84 & 0.50 & 0.01 \\
\hline 寄与率 & $40.1 \%$ & $32.9 \%$ & $16.8 \%$ & $10.0 \%$ & $0.2 \%$ \\
\hline
\end{tabular}

表4 主成分負荷量

\begin{tabular}{|c|c|c|c|c|c|}
\hline 主成分負荷量 & PC1 & $\mathrm{PC} 2$ & PC3 & PC4 & PC5 \\
\hline ぞ & 0.82 & 0.18 & 0.19 & -0.51 & -0.03 \\
\hline なむ & 0.52 & -0.50 & 0.59 & 0.35 & -0.02 \\
\hline や & -0.18 & -0.93 & 0.12 & -0.29 & 0.05 \\
\hline か & -0.93 & -0.22 & 0.21 & -0.17 & -0.06 \\
\hline こそ & -0.39 & 0.67 & 0.63 & -0.06 & 0.04 \\
\hline
\end{tabular}

表5 主成分得点

\begin{tabular}{|l|r|r|r|r|r|}
\hline \multicolumn{1}{|c|}{ 主成分得点 } & PC1 & PC2 & PC3 & PC4 & PC5 \\
\hline 伊勢物語 & 0.56 & -1.62 & 0.97 & 0.96 & -0.06 \\
\hline 土佐日記 & 2.30 & -0.41 & -0.02 & -1.07 & -0.03 \\
\hline 枕草子 & -1.10 & 1.01 & 1.44 & -0.43 & 0.07 \\
\hline 更級旦記 & -0.07 & -0.30 & -0.31 & 0.19 & 0.16 \\
\hline 宇治拾遺物語 & 1.05 & 1.50 & -0.89 & 0.75 & 0.02 \\
\hline 徒然草 & -0.97 & 1.27 & -0.14 & -0.04 & -0.15 \\
\hline おくの細道 & -1.78 & -1.46 & -1.05 & -0.36 & -0.01 \\
\hline
\end{tabular}

表3より PC1、PC2、PC3で90\%以上の情報量を 維持していることがわかる。表4の主成分負 荷量からは、PC1は「ぞ」(+)、「か」(-)で あり、PC2「こそ」(+)、「や」(-) となって いる。「ぞ」も「こそ」もどちらも強調を意 
味するものであるが、半藤英明の著述によれ ば、違いが指摘されている。「ぞ」は“その 点である”という絶対個別化、「こそ」は“こ れであって欲しい”という願望である。この

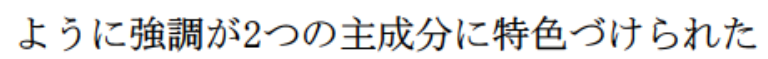
事は大変興味深い。本稿ではその部分には立 ち入らないが、表5の主成分得点より、PC1 については、「土佐日記」(+)、「おくの細 道」(-)であり、PC2については、「宇治拾遺 物語」(+)、「伊勢物語」「おくの細道」が (-) である。また、このことより、この係助

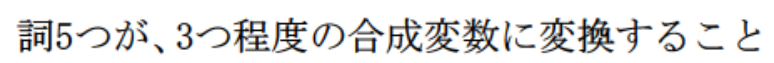
が可能かと思われるため、クラスター数も 3 つ程度と考えても差しさわりないと思われ る。

\section{4 作品の段 (章)の分析}

最初に図1で示した最も近い距離にある 「宇治拾遺物語」と「徒然草」について混合 した段 (章) データでクラスター分析を試み た。全体で400を超えるデータになりクラス ター分析の樹形図が明瞭でなくなるので、ラ ンダムに各々 30 段 (章) ずつ抜出し合計 60

段 (章) データでクラスター分析を試みた。 これを何回か繰り返した。結果の一例を表6 に記す。表6のNo. 1から30が「徒然草」、No. 31 から60が「宇治拾遺物語」である。なおK平 均法 $(K=3)$ のクラスター分析の結果が図3

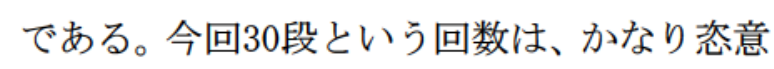
的なものであるが、「宇治拾遺物語」は「徒 然草」とはかなり違うように見える。

\section{表6 クラスター分析の結果}

\begin{tabular}{|r|r|r|r|r|r|r|r|r|r|r|r|r|}
\hline$[1]$ & 3 & 1 & 2 & 2 & 2 & 2 & 2 & 1 & 2 & 1 & 1 & 3 \\
\hline$[13]$ & 1 & 1 & 1 & 1 & 2 & 1 & 1 & 1 & 1 & 1 & 1 & 1 \\
\hline$[25]$ & 1 & 1 & 1 & 1 & 1 & 1 & 1 & 1 & 1 & 2 & 1 & 1 \\
\hline$[37]$ & 1 & 1 & 1 & 1 & 1 & 1 & 1 & 1 & 1 & 1 & 1 & 1 \\
\hline$[49]$ & 1 & 1 & 1 & 1 & 1 & 1 & 1 & 1 & 1 & 1 & 1 & 1 \\
\hline
\end{tabular}

さらに、「伊勢物語」「枕草子」「宇治 拾遺物語」「徒然草」の 4 作品について各 段（章）の頻度データを計測して、作品間 の類似度を計測した。分析方法としては 2 作品の段の頻度を混ぜ合わせたデータから 作品を分離することが可能かという点で、 判別分析を試みた。ただし、これらのデー 夕には、判別分析の前提条件である正規性 の条件と等共分散の条件は満足していなか った。現実データではこれらの条件を完全 に満足するのは難しいと思われる。これら のことより、判別関数についての統計的な 値はあまり信用できないかも知れないが、 あえて判別分析を試みた。

表7より、判別関数の有意性に関しては、 一部有意でない係数もあるが、大半の係数で 有意な結果となっている。表8は、この判別 関数を用いて 2 作品を分離した場合の判別割 合（他の作品に識別される段数/当該作品の 総段数）を記した。上記の結果より「宇治拾 遺物語」は他の作品と混在した場合に、判別 される割合が高い。これは何を意味するので あろうか。おそらく「宇治拾遺物語」は各段

(章) が他の作品に比して、互いに近い位置 にあると思われる。これは図示すると図2の イメージになる。また「伊勢物語」は、作品 中で最も判別が難しいと思われる。「伊勢物 語」は、平安初期の歌物語であるため、文体 が他とは異なっているためではないかと思 われる。

確認のため、この4作品の標準偏差を計測 してみると表8になる。明らかに「宇治拾遺 物語」は4作品中で最も小さな値となってい る。また、「枕草子」と「徒然草」は判別が 難しい。これは両作品が「係助詞」という側 面で非常に似ている傾向があると思われる。 
表 7 判別分析結果

\begin{tabular}{|c|c|c|c|c|c|c|c|c|}
\hline \multicolumn{2}{|c|}{ 判別関数 } & & ぞ & なむ & や & か & こそ & 定数項 \\
\hline \multirow{2}{*}{ 徒然草 } & \multirow{2}{*}{ 宇治拾遺物語 } & 係数 & 16.919 & 145.118 & -40.67 & -11.234 & -54.052 & 0.175 \\
\hline & & F値 & 1.222 & 12.585 & 3.815 & 0.276 & 17.754 & \\
\hline \multirow{2}{*}{ 徒然草 } & \multirow{2}{*}{ 枕草子 } & 係数 & 47.192 & -57.662 & 14.862 & 57.455 & -7.406 & -0.308 \\
\hline & & F值 & 14.129 & 2.031 & 0.963 & 9.228 & 0.609 & \\
\hline \multirow{2}{*}{ 徒然草 } & \multirow{2}{*}{ 伊勢物語 } & 係数 & -8.968 & 194.698 & 60.096 & -6.013 & -47.452 & -0.429 \\
\hline & & F值 & 0.374 & 51.362 & 14.045 & 0.089 & 11.941 & \\
\hline \multirow{2}{*}{ 宇治拾遺物語 } & \multirow{2}{*}{ 枕草子 } & 係数 & 102.055 & 135.874 & -27.368 & 63.575 & -75.349 & -0.289 \\
\hline & & F值 & 29.711 & 9.356 & 1.877 & 5.136 & 31.378 & \\
\hline \multirow{2}{*}{ 宇治拾遺物語 } & \multirow{2}{*}{ 伊勢物語 } & 係数 & -22.402 & 133.102 & 104.073 & 33.961 & -47.374 & -0.644 \\
\hline & & F值 & 1.193 & 24.011 & 30.763 & 1.752 & 2.627 & \\
\hline \multirow{2}{*}{ 枕草子 } & \multirow{2}{*}{ 伊勢物語 } & 係数 & 26.71 & 212.128 & 77.2 & 46.238 & -65.569 & -0.726 \\
\hline & & F値 & 2.203 & 50.664 & 22.756 & 3.365 & 19.885 & \\
\hline
\end{tabular}

\begin{tabular}{|l|r|r|}
\hline 判別割合 & 伊勢物語 & 枕草子 \\
\hline 伊勢物語 & 0.584 & 0.416 \\
\hline 枕草子 & 0.146 & 0.854 \\
\hline
\end{tabular}

\begin{tabular}{|l|r|r|}
\hline 判別割合 & 宇治拾遺物語 & \multicolumn{1}{c|}{ 伊勢物語 } \\
\hline 宇治拾遺物語 & 0.837 & 0.163 \\
\hline 伊勢物語 & 0.464 & 0.536 \\
\hline
\end{tabular}

\begin{tabular}{|l|r|r|}
\hline 判別割合 & 伊勢物語 & 徒然草 \\
\hline 伊勢物語 & 0.504 & 0.496 \\
\hline 徒然草 & 0.156 & 0.844 \\
\hline
\end{tabular}

\begin{tabular}{|l|r|r|}
\hline 判別割合 & 宇治拾遺物語 & \multicolumn{1}{|c|}{ 枕草子 } \\
\hline 宇治拾遺物語 & 0.750 & 0.250 \\
\hline 枕草子 & 0.220 & 0.780 \\
\hline
\end{tabular}

\begin{tabular}{|l|r|r|}
\hline 判別割合 & \multicolumn{1}{|c|}{ 枕草子 } & 徒然草 \\
\hline 枕草子 & 0.699 & 0.301 \\
\hline 徒然草 & 0.512 & 0.488 \\
\hline
\end{tabular}

\begin{tabular}{|l|r|r|}
\hline 判別割合 & 宇治拾遺物語 & \multicolumn{1}{|c|}{ 徒然草 } \\
\hline 宇治拾遺物語 & 0.781 & 0.219 \\
\hline 徒然草 & 0.160 & 0.840 \\
\hline
\end{tabular}

表8 標準偏差

\begin{tabular}{|l|c|c|c|c|c|}
\hline & ぞ & なむ & や & か & こそ \\
\hline 伊勢物語 & 0.008527 & 0.006472 & 0.009942 & 0.006784 & 0.005891 \\
\hline 枕草子 & 0.005815 & 0.001984 & 0.005841 & 0.003726 & 0.008634 \\
\hline 宇治拾遺物語 & 0.003886 & 0.002506 & 0.003063 & 0.003200 & 0.003216 \\
\hline 徒然草 & 0.008292 & 0.002381 & 0.006029 & 0.005721 & 0.010003 \\
\hline
\end{tabular}

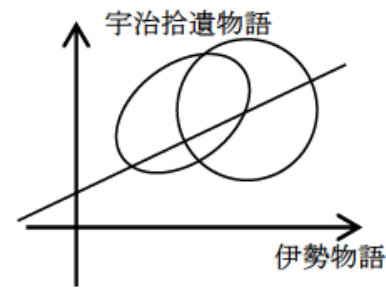

図2 判別分析のイメージ図

\section{3 考察}

今回の分析は、中世の古典で定番の「係 り結び」を構成する「係助詞」のみに着目 した計測であったが、これより以下のこと が推測される。

(1) 平安時代、鎌倉時代と時代を追って「係 り結び」は衰退している。

(2)「枕草子」と「徒然草」は「係助詞」 の使い方の傾向が似ている。
（3「宇治拾遺物語」は全段（章）にわた り、「係助詞」の使い方がある程度統

一されている可能性がある。

(2)は作者が個人であり、個人の感情に基づ いた日記・随筆的な作品であり、(3)は作 者・設立時期が不明で、仏教説話・世俗説 話などの特定個人の感情が入らないよう に編纂された作品との違いを意味するも のであろう。「係助詞」のみから軽々しく 
は断定できないが、「宇治拾遺物語」は文 章全体に特定のルールを用いて書かれた ような均整があるのではと推測される。

\section{謝辞}

本分析を進めるにあたり、サンテクノカ レッジ・コンピュータコミュニケーション 科 4 年生の石川源喜くんをはじめとする 数人の学生さんには作業のお手伝いを頂 きましたことに、心より感謝の意を表しま す。

\section{参考文献}

[1］亀井孝; 大藤時彦; 山田俊雄：「日本語 の歴史 $4 」$, 平凡社, pp. 243-254, 2007

［2］山口仲美：「日本語の歴史」, 岩波新 書, pp. 88- 125, 2006

[3]村上征勝; 今西祐一：「源氏物語助動詞 の計量分析」, 情報処理学会論文誌, vol. 40, no. 3, pp. 774-782， 1999-03

[4]安本美典：「文体統計による筆者推定一 源氏物語, 宇治十帖の作者について」, 心理学評論, pp147-156, 1958

［5］木村文明; 手塚太郎; 前田亮：『古典史 料における人名・地名を用いたテキス トマイニング』, 情報知識学会研究報告, Vo12010-IFAT-100 No2

[6] 北原慈子：「古典文学研究における計量 文献学的手法をめぐって『更級日記』 『浜松中納言物語』『夜半の寝覚』『紫 式部日記』を題材として」, 立命館大 学言語科学研究第 5 巻, 2014

[7]伊勢物語,

http://teppou13. fc2web. com/hana/na rihira/ise/old/ise_story_old. html
[8]土佐日記, http://www. aozora. gr. jp/cards/0001 55/files/832_16016.htm1

[9]枕草子, http://www. geocities. jp/rikwhi/nyu mon/az/makuranosousi_zen. html

[10]更級日記, http://www. asahi-net. or. jp/ ${ }^{\sim} \mathrm{KC} 2 \mathrm{H}-\mathrm{M}$ $\mathrm{SM} / \mathrm{pbsb} /$ sarasina. htm

[11]宇治拾遺物語, http://www. koten. net/uji/

[12]徒然草, http://www. geocities. jp/rikwhi/nyu mon/az/turezure_zen. htm1

[13]おくの細道, http://www. hirama. net/wiki/wiki.cg i/okuno?page=\%A1\%D6\%A4\%AA\%A4\%AF\%A4 \%CE\%A4\%DB\%A4\%BD\%C6\%BB\%A1\%D7\%C1\%B4\% CA\%B8

[14] 半藤英明：「係助詞と係結びの本質」, 新典社研究叢書, pp. 97-114, 2003.

[15]青木繁伸：「Rによる統計解析」，オー 厶社, 2009

[16］福井正康：「College Analysis」 http://www. heisei-u. ac. jp/ba/fukui /analysis. html 